\title{
Acceptability of kefir produced by fermentation of Portuguese milk with CIDCA AGK1 grains in a sample of Portuguese consumers
}

\author{
Aceitabilidade do kefir produzido pela fermentação do leite português com grãos CIDCA AGK1 \\ numa amostra de consumidores portugueses
}

\section{Emília Alves, Patrícia Rijo, Luís Monteiro Rodrigues, Catarina Rosado*}

CBIOS - Universidade Lusófona's Research Center for Biosciences and Health Technologies, Av. Campo Grande 376, 1749-024 Lisbon, Portugal

*corresponding author: catarina.rosado@ulusofona.pt

\begin{abstract}
Fermented foods, such as kefir, tend to be characterized by their unique flavor and aroma. Sensory perception of this type of food or beverage is a key factor for the general consumer acceptance of the product, which can be assessed through sensory tests. Conventional sensory tests include acceptance tests where consumers, not trained panelists, are asked to express their degree of like on a hedonic scale, where the level of acceptability of foods does not require a choice between alternatives. The most commonly used scale for testing consumer acceptability of foods is the 9-point hedonic scale. An average score of 7 or higher on the acceptability test indicates a high sensory quality and represents a good acceptance of the product by the panel. This study aimed to evaluate the acceptance of a kefir drink in a sample of Portuguese consumers. The acceptability test of the kefir obtained by fermentation of Portuguese milk with CIDCA AGK1 kefir grains was conducted in a group of 19 consumers using a 9-point hedonic scale and produced a mean score of $7.00 \pm 1.15$, which correlates with a qualitative rating of "Like moderately." This work is part of an ongoing study, designated DermapBio, conducted by our research center, with an aim to evaluate the benefits of kefir ingestion for cutaneous health.
\end{abstract}

Keywords: Kefir, fermented dairy, sensory perception, acceptability test, hedonic scale

\begin{abstract}
Resumo
Alimentos fermentados, como o kefir, tendem a ser caracterizados pelo seu sabor e aroma únicos. A percepção sensorial deste tipo de alimento ou bebida é um fator chave para a aceitação geral do produto pelo consumidor, e pode ser avaliada por testes sensoriais. Testes sensoriais convencionais incluem testes de aceitação, onde os consumidores, provadores não treinados, são solicitados a expressar o grau de preferência numa escala hedónica que não exige uma escolha entre alternativas. A escala mais vulgarmente usada para testar a aceitação de alimentos pelo consumidor é a escala hedónica de 9 pontos. Uma pontuação média igual ou superior a 7 no teste de aceitabilidade indica uma elevada qualidade sensorial e representa uma boa aceitação do produto pelo painel. Este estudo teve como objetivo avaliar a aceitação da bebida kefir numa amostra de consumidores portugueses. $O$ teste de aceitabilidade do kefir, obtido pela fermentação de um leite português com grãos de kefir CIDCA AGK1, foi realizado num grupo de 19 consumidores usando uma escala hedónica de 9 pontos, produziu uma pontuação média de $7,00 \pm 1,15$, o que se correlaciona com uma avaliação qualitativa de "Moderadamente agradável". Este trabalho enquadra-se num estudo in-use que pretende avaliar os benefícios da ingestão de kefir para a saúde cutânea, conduzido pelo nosso centro de investigação e codificado como DermapBio.
\end{abstract}

Palavras-chave: Kefir, leite fermentado, percepção sensorial, teste de aceitabilidade, escala hedónica 


\section{Introduction}

Kefir is a unique fermented, slightly carbonated, dairy beverage known for its organoleptic characteristics. It originated from the Caucasus, and has been traditionally consumed for centuries in several countries in Eastern Europe (1). Traditional production uses kefir grains as a natural starter, which differentiates this beverage from other fermented milk (2). Kefir can be made from different kinds of milk (cow, goat, sheep, camel, buffalo) and is characterized by an acid and slightly yeasty taste which, combined with the carbon dioxide produced by the yeast flora, confers a prickly sensation that can be considered as its typical flavor (3). Fermented foods, such as kefir, tend to be characterized by their unique flavor and aroma (3). Sensory perception of this type of food is a key factor for the general consumer acceptance of such products, and can be assessed by sensory tests $(4,5)$. In the food industry, sensory evaluation methods used in dairy products include affective or consumers tests, among others (6). By definition, these tests are applied only to a naïve (untrained) panel, since trained panels are potentially more critical and more sensitive than the average consumer, thus ceasing to be considered a typical consumer assessment (4). Affective tests are used to assess consumer likes and dislikes, and the most typical are preference tests and acceptance tests $(5,7)$. In preference tests, consumers are presented with several samples and are required to choose between them, that is, a preference must be indicated. In acceptance tests, also called degree of liking, consumers are asked to indicate the degree of liking on a scale where the degree of acceptability of foods does not require a choice between alternatives $(4,7)$. The most commonly used scale for testing consumer acceptability of foods is the 9-point hedonic scale (8-12). This scale can be presented numerically or verbally, horizontally or vertically, although such structural variations have no critical effect on the results (13). It is a bipolar scale with four positive and four negative categories on each side of a neutral center. The hedonic scale uses the anchors like and dislike, thus assuming a continuum degree of affection in the consumers' preferences which can be categorized based on the like/dislike answers. This approach provides information on the product in a broader sense then a simple choice of yes or no $(7,13)$. In rating scales, the selection of the anchor words must be meaningful and clear to the participants, must be related to the specific scale, and must prevent misinterpretation. Scoring in these scales is used with the main purpose of determining the magnitudes of the differences identified (14). In the 9-point hedonic scale, answers are usually assigned values between 1 and 9,

\section{Introdução}

Kefir é uma bebida láctea fermentada, um pouco efervescente, conhecida pelas suas características organolépticas únicas, originária do Cáucaso e tradicionalmente consumida desde há séculos em vários países do Leste Europeu (1). A sua produção tradicional usa grãos de kefir como iniciador, o que diferencia esta bebida de outros leites fermentados (2). O kefir pode ser feito a partir de diferentes tipos de leite (vaca, cabra, ovelha, camelo, búfalo) e é caracterizado por um sabor ácido e levemente fermentado que, combinado com o dióxido de carbono produzido pelas leveduras, lhe confere uma sensação de efervescência e que pode ser considerado como o seu sabor típico (3). Alimentos fermentados, como o kefir, tendem a ser caracterizados pelo seu sabor e aroma únicos (3). A percepção sensorial, desde tipo de alimento é um fator chave para a aceitação destes produtos pelo consumidor em geral e pode ser avaliada por testes sensoriais $(4,5)$. Na indústria alimentar, os métodos de avaliação sensorial usados em laticínios incluem, entre outros, testes afetivos ou de consumo. Por definição, estes são aplicados apenas a um painel ingénuo (não treinado), uma vez um painel treinado é potencialmente mais crítico e mais sensível do que o consumidor médio, deixando assim de ser considerado avaliação típica de consumidor (4). Testes afetivos são usados para avaliar o gosto/não gosto do consumidor, sendo os mais comuns, os testes de preferência e os testes de aceitação $(5,7)$. Nos testes de preferência os consumidores são apresentados a várias amostras e são obrigados a escolher entre elas, ou seja, deve ser indicada uma preferência. Nos testes de aceitação, também denominados grau de gosto, os consumidores são solicitados a indicar o grau de gosto numa escala em que o grau de aceitabilidade dos alimentos não requer uma escolha entre alternativas (4,7). A escala mais comummente usada para testar a aceitação de alimentos pelo consumidor é a escala hedónica de 9 pontos (812). Esta escala pode ser apresentada numérica ou verbalmente, horizontal ou verticalmente embora tais variações estruturais não tenham efeito crítico sobre os resultados (13). É uma escala bipolar com quatro categorias positivas e quatro negativas de cada um dos lados de um centro neutro. A escala hedónica usa as palavras âncora gosto e não gosto, assumindo assim um grau contínuo de afeto das preferências do consumidor que pode ser categorizado com base nas respostas gosto/ não gosto, fornecendo informações sobre o produto num sentido mais amplo, em vez de uma simples escolha de sim ou não $(7,13)$. Nas escalas de avaliação, a seleção das palavras âncora deve ser significativa 
where a value of 1 correlates with "dislike extremely" and a value of 9 with "like extremely". Using this score, a mean value of 7 or higher is usually indicative of a high sensory quality, resulting in a good acceptance of the product $(7,15)$. When compared to other scaling methods, this scale is a robust way of estimating consumer like due to its simple yet sensitive categories of discriminating power. Its limited number of options also makes it suitable and easy to use for both trained or untrained panelists, thus justifying its wide acceptance $(8,14,15)$. Therefore, when the primary objective of a study is to predict consumer acceptance, the 9-point hedonic scale has proven to be a simple and effective measuring device (8). Based on the fact that the consumption of kefir is not a typical food habit of the Portuguese population, this study aimed to evaluate the acceptance of this beverage in a sample of Portuguese consumers. This work is framed by a study regarding the cutaneous health benefits of kefir intake currently being conducted by our research team and designated as DermapBio .

\section{Materials and Methods}

Kefir beverage was prepared by fermenting semi-skim ULHT Portuguese cow's milk (purchased at a local supermarket) using CIDCA AGK1 kefir grains for 24 hours at $20^{\circ} \mathrm{C}$. CIDCA AGK1 kefir grains were obtained from the Centro de Investigacíon y Desarrollo en Criotecnologia de Alimentos (CIDCA), La Plata, Argentina. The microbiological characterization of these grains has been described elsewhere (16-18). All volunteers were recruited from the DermapBio study conducted at our research centre, thus being a convenience sampling. Due to the fact that this work is part of an in-use study where kefir was consumed, we considered this an exploratory study. The study protocol was submitted to and approved by the ethics committee of the School of Sciences and Health Technologies at Lusofona's University ( $\mathrm{N}^{0} 1 / 2018,15$ th May 2018) e clara para os participantes, deve estar relacionada com a escala específica e deve evitar interpretações erradas. A pontuação nessas escalas é utilizada com o objetivo principal de determinar as magnitudes das diferenças identificadas (14). Na escala hedónica de 9 pontos, atribuem-se geralmente às respostas valores entre 1 e 9, em que 1 se correlaciona com a categoria "extremamente desagradável" e 9 com a categoria "extremamente agradável". Com esta pontuação, um valor médio de 7 ou superior é geralmente indicativo de uma qualidade sensorial elevada resultando numa boa aceitação do produto $(7,15)$. Quando comparada com outros métodos de escalonamento, esta escala é uma forma robusta de estimar o gosto do consumidor devido às suas categorias simples, porém sensíveis, em termos de poder de discriminação. Também o seu número limitado de opções a tornam adequada e fácil de usar, seja por provadores treinados ou não treinados, justificando assim a sua ampla aceitação $(8,13,15)$. Portanto, quando o objetivo principal de um estudo é predizer a aceitação do consumidor, a escala hedónica de 9 pontos tem mostrado ser um instrumento de medição simples e eficaz (8). Atendendo ao facto do consumo de kefir não ser um hábito alimentar típico da população portuguesa, este estudo teve como objetivo avaliar a aceitação desta bebida numa amostra de consumidores portugueses. Este trabalho enquadra-se num estudo inuse que pretende avaliar os benefícios da ingestão de kefir para a saúde cutânea, conduzido pela nosso centro de investigação e codificado como DermapBio.

\section{Material e Métodos}

A bebida kefir foi preparada por fermentação de leite de vaca semidesnatado ULHT português (comprado num supermercado local) usando grãos de kefir CIDCA AGK1, durante 24 horas a $20^{\circ} \mathrm{C}$. Os grãos de kefir CIDCAAGK1 foram obtidos do Centro de Investigacíon y Desarrollo en Criotecnologia de Alimentos (CIDCA), La Plata, Argentina. A caracterização microbiológica desses grãos foi descrita em outro lugar (16-18). Todos os voluntários foram recrutados a partir do estudo DermapBio realizado no nosso centro de investigação, sendo portanto, uma amostra de conveniência. Devido ao fato deste trabalho fazer parte de um estudo in-use, onde o kefir é consumido, este estudo foi considerado um estudo exploratório. O protocolo do estudo foi submetido e aprovado pela comissão de ética da Escola de Ciências e Tecnologias da Saúde da Universidade Lusófona $\left(\mathrm{N}^{\mathrm{o}} 1\right.$ / 2018, 15 de maio de 2018) e foi conduzido de acordo com os princípios da Declaração 
and was conducted according to the principles of the Helsinki Declaration. The prepared kefir was evaluated by a consumer panel using 9-point hedonic scale. The consumer group consisted of 19 volunteers, 94.7\% women and 5.3\% men, aged 19 to 55 years (mean age $29.11 \pm 11.61$ years). The volunteers had no prior experience with kefir consumption. All volunteers were given a white plastic cup with a sample $(100 \mathrm{~mL})$ of freshly made kefir, under controlled conditions, and then were asked to grade the beverage in a 9-point hedonic scale, where the acceptability of the product was evaluated within a score of 1 (dislike extremely) to 9 (like extremely), according to overall acceptability of the product. The scale was presented to the volunteers as a Google form questionnaire (Figure 1). Results were expressed as mean \pm standard deviation (SD) or as relative frequency (\%), and association between variables was performed with Pearson's Chi-Square Test using SPSS statistical package version 25 (SPSS Inc., Chicago, IL, USA). de Helsínquia. O kefir preparado foi avaliado por um painel de consumidores usando uma escala hedónica de 9 pontos. O grupo de consumidores foi constituído por 19 voluntários, 94,7\% mulheres e 5,3\% homens, com idades entre 19 a 55 anos (média de idades $29,11 \pm 11,61$ anos). Nenhum dos voluntários tinha provado kefir antes de participar neste estudo. Todos os voluntários receberam um copo de plástico branco com uma amostra $(100 \mathrm{~mL})$ de kefir acabado de fazer, sob condições controladas, e seguidamente foram solicitados a classificar a bebida numa escala hedónica de 9 pontos, onde a aceitabilidade do produto foi avaliada dentro de uma pontuação de 1 (extremamente desagradável) a 9 (extremamente agradável) de acordo com a aceitabilidade geral do produto. A escala foi apresentada aos voluntários na forma de questionário Google (Figura 1). Os resultados foram expressos como média \pm desvio padrão (DP) ou como frequência relativa (\%), e a associação entre variáveis foi realizada com Teste Qui-quadrado de Pearson usando o pacote estatístico SPSS versão 25 (SPSS Inc., Chicago, IL, EUA).

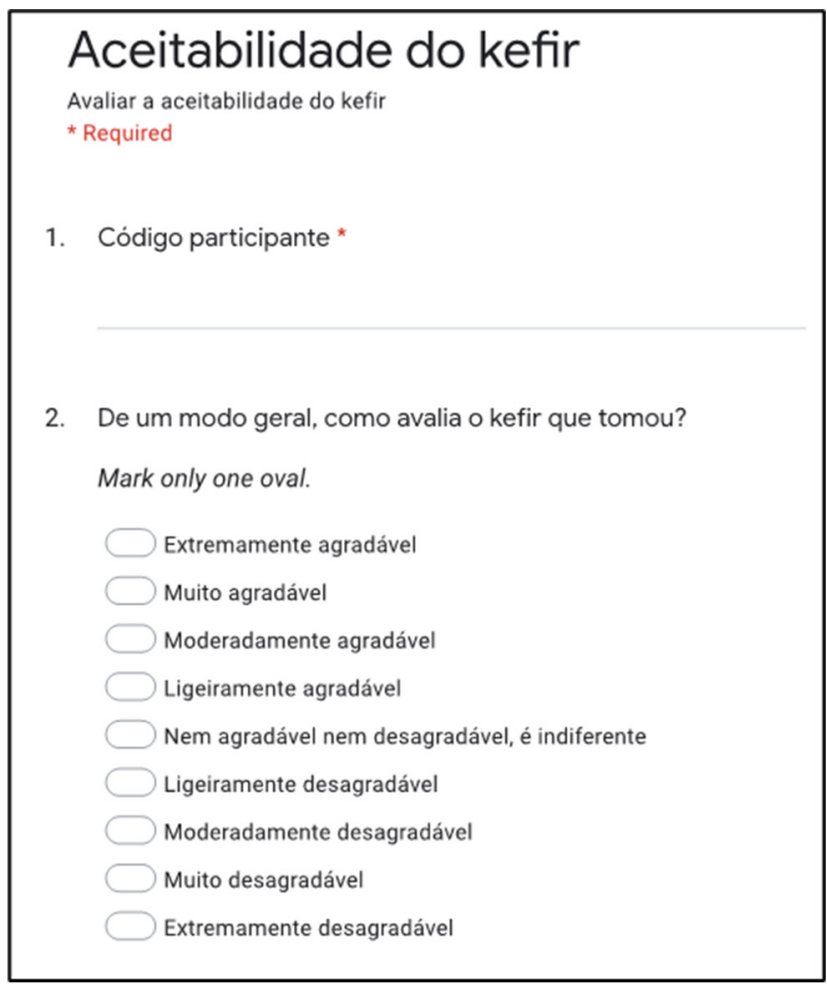

Figure 1 - 9-point hedonic scale translated in Portuguese language, presented as a questionnaire. The kefir consumed was evaluated by each (coded) participant as: dislike extremely [1], dislike very much [2], dislike moderately [3], dislike slightly [4], neither like nor dislike [5], like slightly [6], like moderately [7], like very much [8], or like extremely [9].

Figura 1 - Escala hedónica de 9 pontos traduzida para a língua portuguesa, apresentada na forma de questionário. O kefir consumido foi avaliado por cada participante (codificado) como: extremement desagradável [1], muito desagradável [2], moderadamente desagradável [3], ligeiramente desagradável [4], indiferente [5], ligeiramente agradável [6], moderadamente agradável [7], muito agradável [8], ou extremement agradável [9]. 


\section{Results}

The group of volunteers who participated in the study was characterized socio-demographically (Table 1). Within the study group, $78.9 \%$ were university students, $68.4 \%$ lived in an urban area, and the majority had no smoking habits $(78.9 \%)$. The average Body Mass Index (BMI) of the sample was $21.82 \pm 2.89 \mathrm{~kg} /$ $\mathrm{m}^{2}$. The consumption of dairy products within the panel was mainly through the consumption of natural yogurt $(84.2 \%)$, and $57.9 \%$ of the participants drank cow's milk regularly (Table 1). The results of the acceptability test using this 9-point hedonic scale showed that 58\% of the volunteers assessed the kefir drink as "Like moderately", $32 \%$ as "Like very much" and only $11 \%$ assigned the rating "Dislike slightly" (Figure 2). The average score given by this sample of volunteers to our kefir was $7.00 \pm 1.15$, which is correlates with a "Like moderately" rating, and the acceptability of kefir was not related to the consumption of dairy products, namely, consumption of milk or yogurt $(\mathrm{p}=0.310$ and $\mathrm{p}=0.568$, respectively).

\section{Discussion}

Our results, correlated with a "Like moderately" rating, seem to indicate a reasonable acceptance of kefir by our panel. A classification such as ours can be an indicator of a high quality sensory product (13). Our results were consistent with those obtained by Moretti et al. (14), in which the acceptability of kefir made with CIDCA AGK1 grains, was also tested using untrained panelists $(n=93)$ and a 9-point hedonic scale. In their study, the average score obtained was $7.88 \pm 0.35$ and this result was correlated with a qualitative grade of "Like very much", which indicated a good acceptance of the product by the panel (14).

The use of a 9-point hedonic scale has been widely accepted as a good tool to infer consumer acceptability as it is able to provide internal validity to the test (14). The use of this type of scale for assessment of consumer acceptability of dairy has been confirmed by other researchers $(6,10,14)$. Nevertheless, some weak points have been identified, namely the small number of categories available, the lack of equal intervals between categories, the presence of the neutral category "neither like or dislike" that lessens the scale efficiency, and the general consumer tendency to avoid using the extreme categories, which may increase the scale vulnerability to ceiling effects $(7,11,19)$. A consideration must be

\section{Resultados}

O grupo de voluntários que participaram no estudo foi caracterizado sócio-demograficamente (Tabela 1). Cerca de 78,9 \% eram estudantes universitários, 68,4 \% viviam em área urbana e a maioria não tinha hábitos tabágicos $(78,9 \%)$. O Índice de Massa Corporal (IMC) médio da amostra foi de $21.82 \pm 2.89 \mathrm{~kg} / \mathrm{m}^{2} \mathrm{e}$ o consumo de lacticínios, no painel, foi principalmente devido ao consumo de iogurte natural $(84,2 \%)$ e 57,9 $\%$ dos participantes bebiam leite de vaca regularmente (Tabela 1). Os resultados do teste de aceitabilidade utilizando esta escala hedónica de 9 pontos mostraram que $58 \%$ dos voluntários consideraram a bebida kefir como "Moderadamente agradável", $32 \%$ como "Muito agradável" e apenas $11 \%$ atribuíram a classificação de "Ligeiramente desagradável" (Figura 2). A pontuação média dada por esta amostra de voluntários ao nosso kefir foi de 7,00 $\pm 1,15$ o que equivale a uma classificação de "Moderadamente agradável," e a aceitabilidade do kefir não se relacionou com o consumo de laticínios, nomeadamente, consumo de leite ou iogurte $(p=0,310$ $\mathrm{e} p=0,568$, respectivamente).

\section{Discussão}

Os nossos resultados, correlacionados com uma classificação de "Moderadamente agradável", parecem indicar uma aceitação razoável do kefir pelo nosso painel. Uma classificação como a nossa pode ser indicador de um produto sensorial de alta qualidade (13). Os nossos resultados foram consistentes com os obtidos por Moretti et al. (14), que testou a aceitabilidade de kefir feito a partir de grãos CIDCA AGK1, usando também provadores não treinados $(\mathrm{n}=93)$ e uma escala hedónica de 9 pontos. No seu estudo, o score médio obtido foi de 7,88 $\pm 0,35$ e esse resultado foi correlacionado com uma classificação qualitativa de "Gosto muito", o que indicou uma boa aceitação do produto por parte dos consumidores (14).

O uso de uma escala hedónica de 9 pontos tem sido amplamente aceite como uma boa ferramenta para inferir sobre a aceitabilidade dos consumidores, uma vez que é capaz de fornecer validade interna ao teste (15). O uso deste tipo de escala para avaliação da aceitabilidade do consumidor de produtos lácteos foi confirmado por outros investigadores $(6,10,14)$. No entanto, foram identificados alguns pontos fracos, nomeadamente o pequeno número de categorias disponíveis, a falta de intervalos iguais entre as categorias, a presença 
Table 1 - Sociodemographic characteristics of consumers sample

Tabela 1 - Características sociodemográficas da amostra de consumidores.

\begin{tabular}{lc}
$\begin{array}{l}\text { Sociodemographic Characteristics / } \\
\text { Características sociodemográficas }\end{array}$ & $\begin{array}{c}\text { Portuguese consumers sample / Amostra } \\
\text { de consumidores Portugueses (n=19) }\end{array}$ \\
\hline Gender / Género & $18(94.7)$ \\
Female / Feminino, n (\%) & $1(5.3)$ \\
Male / Masculino, n (\%) & $29.11(11.61)$ \\
Age / Idade, mean (SD) / média (DP), years / anos & \\
Scholarity / Escolaridade & $16(84.2)$ \\
High School (12th grade) / & $3(15.8)$ \\
Ensino Secundário (12 ${ }^{\circ}$ ano), n (\%) & \\
Doctorate / Doutoramento, n (\%) & $3(15.8)$ \\
Career / Profissão & $15(78.9)$ \\
Professor / Professor, n (\%) & $1(5.3)$ \\
University student / Estudante universitário, n (\%) & \\
Entrepreneur / Empresário, $\mathrm{n}(\%)$ & $13(68.4)$ \\
Residence / Residência & $6(31.6)$ \\
Urban / Urbano, n (\%) & \\
Rural / Rural, n (\%) & $15(78.9)$ \\
Smoking habits / Hábitos tabágicos & $3(21.4)$ \\
Non smoker / Não fumador, n (\%) & $1(7.1)$ \\
Occasional smoker / Fumador ocasional, n (\%) & $21.82(2.89)$ \\
Smoker / Fumador, n (\%) & $11(57.9)$ \\
BMI / IMC, mean (SD) / média (DP), kg/m² & $16(84.2)$ \\
Dairy consumption / Consumo de laticínios & $5(26.3)$ \\
Cow milk / Leite de vaca, $\mathrm{n}(\%)$ & \\
Natural yogurt / Iogurte natural, $\mathrm{n}(\%)$ & \\
Vegetable drink / Bebida vegetal, $\mathrm{n}(\%)$ & \\
\hline
\end{tabular}

SD - Standard Deviation / DP - Desvio Padrão; BMI - Body mass Index / IMC - Índice de Massa Corporal.

made about the use of a scale that was translated to Portuguese language. As demonstrated by Curia et al. (20) regarding the Spanish language, the use of the 9-point hedonic scale in languages different from English must be done with caution, as the general population may fail to perceive the translations with the same meaning as they have in English, especially with regard to the extreme categories of the scale (20). To the best of our knowledge, the translation of this scale into Portuguese has not yet been validated and, as such, care should be taken in generalizing the conclusions drawn. It should be noted that acceptance tests (consumer liking tests) should preferably be carried out with a larger number of individuals (6). Some authors recommend 50 consumers as the minimum desirable to guarantee the accuracy of the statistical analysis and to be able to draw conclusions product acceptance (not applicable to da categoria neutra "nem gosto, nem não gosto" que diminui a eficiência da escala e a tendência geral do consumidor em evitar usar as categorias extremas, que podem aumentar a vulnerabilidade da escala aos efeitos de teto $(7,11,19)$. Devemos ainda ter em consideração o facto de termos usado uma escala que foi traduzida para a língua portuguesa. Conforme demonstrado por Curia et al. (20) para a língua espanhola, o uso da escala hedónica de 9 pontos em outras línguas diferentes do inglês deve ser feito com cautela, pois a população em geral pode não perceber as traduções com o mesmo significado que elas possuem em inglês, especialmente no que diz respeito às categorias extremas da escala (20). Até onde sabemos, a tradução desta escala para a língua portuguesa ainda não foi validada e, como tal, devemos ter alguma precaução na generalização das conclusões tiradas. De notar que os testes de 
trained tasters) $(5,6,8)$. Furthermore, because we used a convenience sample of volunteers already willing to participate in a study involving kefir consumption for eight weeks, the main disadvantage of which is the lack of clear generalization (21), we cannot extrapolate our results to the general population. Therefore, due to the type of sampling and the limited number of consumers used in our study, we cannot fully infer about the acceptability of kefir for Portuguese consumers. Nevertheless, these results can provide an indication of how the product is viewed by consumers with no previous contact with this beverage. Hedonic opinions, such as food choice, are affected by environmental context and individual expectations $(22,23)$. Both the intra- and the inter-variability of consumers may influence the product acceptance throughout time $(7,22,23)$. In general, the individual like/dislike stimuli may be influenced by environment, for example, type of meal, time of day, number of times the food has been consumed recently or temperature of the food, thus increasing the difficulty of measuring a stable attitude toward a certain food $(7,24)$. As stated by Lawless \& Heymann (2010), habits, experiences, contexts and attitudes are important contributors to the actual consumption of a food in a specific situation (7). Since the participants in our study were all part of the same group and so, were not blind to kefir consumption, this aceitação (testes de gosto do consumidor) devem ser realizados preferencialmente com um grande número de indivíduos (6). Alguns autores recomendam que 50 consumidores como o mínimo desejável para garantir a precisão da análise estatística, podendo, assim, concluir sobre a aceitação do produto (não aplicável a provadores treinados) $(5,6,8)$. Além disso, porque utilizámos uma amostra de conveniência, com voluntários já dispostos a participar num estudo envolvendo o consumo de kefir por oito semanas, cuja principal desvantagem é a falta de generalização clara (21), não podemos extrapolar os nossos resultados para a população em geral. Portanto, devido ao tipo de amostragem e ao número limitado de consumidores usados no nosso estudo, não podemos inferir completamente sobre a aceitabilidade do kefir para o consumidor português. No entanto, estes resultados podem fornecer uma indicação de como o produto é visto por consumidores sem contato prévio com este bebida. As opiniões hedónicas, como a escolha alimentar, são afetadas pelo contexto ambiental e pelas expectativas individuais $(22,23)$. A intra e a intervariabilidade dos consumidores podem, ambas, influenciar a aceitação do produto ao longo do tempo (7,22,23). Em geral, os estímulos individuais de gosto/ não gosto podem ser influenciados pelo contexto ambiental, como por exemplo, pelo tipo de refeição, hora do dia, número de vezes que o alimento foi

\section{Kefir acceptability / Aceitabilidade do kefir}

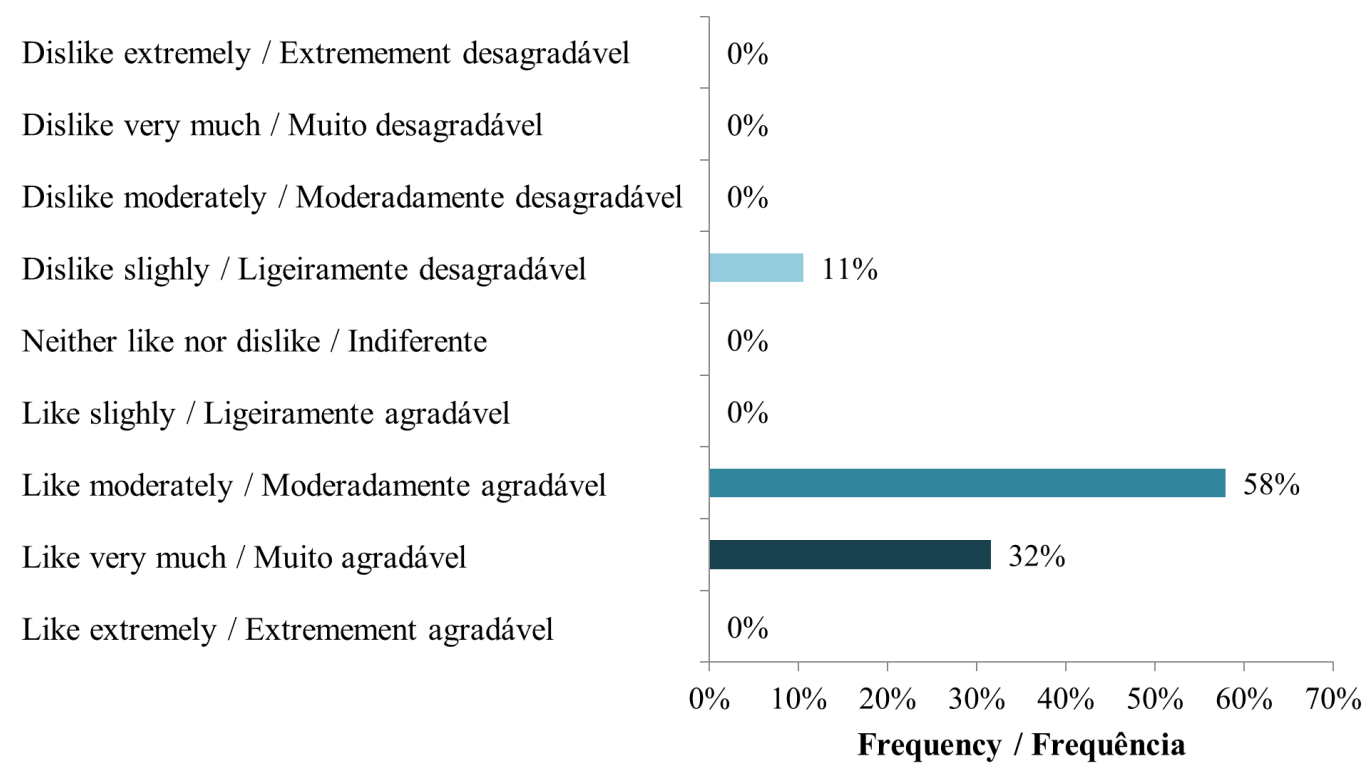

Figure 2 - Kefir acceptability in a sample of Portuguese consumers based on the 9-point hedonic scale (frequency $(\%), n=19)$

Figura 2.- Aceitabilidade do kefir numa amostra de consumidores portugueses baseada na escala hedónica de 9 pontos (frequência $(\%), n=19)$. 
factor may have influenced the individual choices of the volunteers, despite the fact that the scale was presented to each participant individually. Nevertheless, these results support the adoption of the protocol applied to our in-use "DermapBio" study of the impact on the skin health of kefir consumption conducted by our research team, as during the study this beverage must be taken daily.

\section{Conclusion}

General consumer acceptance of fermented foods, such as kefir, that are characterized by their unique flavor and aroma are mainly dependent of their sensory perception. Although kefir is not traditionally consumed in Portugal, our kefir drink showed a good acceptance in this sample of consumers and supports the protocol adopted in a posterior study.

\section{Author Contributions Statement}

PR, CR, LMR, and EA conceptualization and study design; EA experimental implementation; EA and CR data analysis; EA illustrations; EA, PR and CR drafting editing and reviewing

\section{Funding}

This work is financed by national funds through the FCT - Foundation for Science and Technology, I.P., through projects UIDB/04567/2020 and UIDP/04567/2020 to CBIOS.

\section{Conflict of Interests}

The senior editors co-authoring this manuscript had no participation in the review nor in the decision process.

All authors have declared there were no financial and/ or personal relationships that may present a potential conflict of interest. consumido recentemente ou temperatura do alimento, aumentando assim a dificuldade de medir uma atitude estável em relação a um determinado alimento $(7,24)$. Como afirmam Lawless \& Heymann (2010), hábitos, experiências, contextos e atitudes são importantes contribuintes para o consumo real de um alimento numa situação específica (7). Dado que os participantes no nosso estudo faziam parte do mesmo grupo e, portanto, não eram cegos ao consumo de kefir, esse fator pode ter influenciado nas escolhas individuais dos voluntários, apesar de a escala ter sido apresentada a cada participante individualmente. No entanto, estes resultados apoiam a adoção do protocolo aplicado a nossa estudo in-use "DermapBio" do impacto do consumo de kefir na saúde da pele, conduzido pela nossa equipa de investigaçãom, á que este bebida deve ser tomado diariamente.

\section{Conclusões}

A aceitação pelo consumidor em geral de alimentos fermentados, como o kefir, que são caracterizados pelo seu sabor e aroma únicos, depende principalmente da sua percepção sensorial. Embora o kefir não seja tradicionalmente consumido em Portugal, a nossa bebida kefir mostrou uma boa aceitação nesta amostra de consumidores e apoia o protocolo adotado num estudo posterior.

\section{Declaração sobre as contribuições do autor}

PR, EA, LMR e CR, Conceptualização e desenho de estudos; EA implementação experimental; EA e CR Análise de dados; EA ilustrações;EA PR e CR, edição e revisão da redação

\section{Financiamento}

Este trabalho é financiado com fundos nacionais através da FCT - Fundação para a Ciência e Tecnologia, I.P., no âmbito dos projetos UIDB/04567/2020 and UIDP/04567/2020 do CBIOS.

\section{Conflito de Interesses}

Os editores senior envolvidos na autoria deste manuscrito não tiveram qualquer participação no processo de revisão ou de decisão.

Todos os autores declararam não haver relações financeiras e/ou pessoais que possam representar um potencial conflito de interesses. 


\section{References / Referências}

1. Farnworth, E.R. (2005). Kefir-A complex probiotic. Food Science and Technology Bulletin: Functional Foods, 2, 1-17. doi:10.1616/14762137.13938.

2. Simova, E., Beshkova, D., Angelov, A., Hristozova, Ts., Frengova, G., Spasov, Z. (2002). Lactic acid bacteria and yeasts in kefir grains and kefir made from them. Journal of Industrial Microbiology and Biotechnology, 28(1), 1-6. doi:10.1038/sj/jim/7000186.

3. Irigoyen, A., Arana, I., Castiella, M., Torre, P., Ibañez, F.C. (2005). Microbiological, physicochemical, and sensory characteristics of kefir during storage. Food Chemistry, 90, 613-620. doi:10.1016/j.foodchem.2004.04.021.

4. Drake, M.A. (2007). Invited Review: Sensory Analysis of Dairy Foods. Journal of Dairy Science, 90, 4925-4937. doi:10.3168/jds.20070332 .

5. Lawless, H.T., Heymann, H. (1999). Consumer field tests and questionnaire design. In H.T. Lawless, H. Heymann (Eds.), Sensory Evaluation of Food, 1st Ed. (pp 480-514). New York, NY: Chapman and Hall.

6. Moskowitz, H. R., Beckley, J. H., \& Resurreccion, A. V. A. (2012). Sensory and Consumer Research in Food Product Design and Development (H. R. Moskowitz, J. H. Beckley, \& A. V. A. Resurreccion (eds.); 2nd ed.). Wiley-Blackwell.

7. Lawless, H.T., Heymann, H. (2010). Acceptance Testing. In H.T. Lawless, H. Heymann (Eds.), Sensory Evaluation of Food (pp. $325-$ 344). doi:10.1007/978-1-4419-6488-5_14.

8. Lim, J. (2011). Hedonic scaling: A review of methods and theory. Food Quality and Preferences, 22, 733-747. doi:10.1016/j. foodqual.2011.05.008.

9. Illupapalayam, V. V., Smith, S. C., \& Gamlath, S. (2014). Consumer acceptability and antioxidant potential of probiotic-yogurt with spices. LWT - Food Science and Technology, 55(1), 255-262. https://doi.org/10.1016/j.lwt.2013.09.025

10. Cruz, A. G., Walter, E. H. M., Cadena, R. S., Faria, J. A. F., Bolini, H. M. A., Pinheiro, H. P., \& Sant'Ana, A. S. (2010). Survival analysis methodology to predict the shelf-life of probiotic flavored yogurt. Food Research International, 43(5), 1444-1448. https://doi. org/10.1016/j.foodres.2010.04.028.

11. Schutz, H.G., Cardello, A.V. (2001). A labeled affective magnitude (LAM) scale for assessing food liking/disliking. Journal of Sensorial Studies, 16, 117-159.

12. Stone, H., Bleibaum, R.N., Thomas, H.A. (2012). Measurement. In H. Stone, R.N. Bleibaum \& H. Thomas (Eds.). Sensory Evaluation Practices (pp. 81-115). doi:10.1016/b978-0-12-382086-0.00003-0.

13. Everitt, M. (2009). Consumer-targeted sensory quality. In G. Barbosa-Cánovas, A. Mortimer, D. Lineback, W. Spiess, K. Buckle, \& P. Colonna (Eds.). Global issues in food science and technology (pp. 117-128). doi: 10.1016/B978-0-12-374124-0.00008-9.

14. Moretti, A.F., Gamba, R.R., Costa, M., De Antoni, G., Peláez, Á.L. (2019). Protective Effect of Lyophilization on Fermentative, Microbiological and Sensory Properties of Kefir. International Journal of Biochemistry and Pharmacology, 1(1), 5-11. doi: 10.18689/ ijbp-1000102.

15. Van Trijp, H.C.M., Schifferstein, H.N.J. (1995). Sensory analysis in marketing practice: comparison and integration. Journal of Sensorial Studies, 10, 127-147. doi.org/10.1111/j.1745-459X.1995.tb00010.x.

16. Garrote, G. L., Abraham, A. G., \& De Antoni, G. L. (2001). Chemical and microbiological characterisation of kefir grains. Journal of Dairy Research, 68(4), 639-652. https://doi.org/10.1017/S0022029901005210.

17. Hamet, M. F., Londero, A., Medrano, M., Vercammen, E., Van Hoorde, K., Garrote, G. L., Huys, G., Vandamme, P., \& Abraham, A. G. (2013). Application of culture-dependent and culture-independent methods for the identification of Lactobacillus kefiranofaciens in microbial consortia present in kefir grains. Food Microbiology, 1-33. https://doi.org/10.1016/j.fm.2013.06.022.

18. Diosma, G., Romanin, D. E., Rey-Burusco, M. F., Londero, A., \& Garrote, G. L. (2014). Yeasts from kefir grains: Isolation, identification, and probiotic characterization. World Journal of Microbiology and Biotechnology, 1-11. https://doi.org/10.1007/s11274-013-1419-9.

19. Lim, J., Fujimaru, T. (2010). Evaluation of the labeled hedonic scale under different experimental conditions. Food Quality and Preference, 21, 521-530. https://doi.org/10.1016/j.foodqual.2010.02.001.

20. Curia, A.V., Hough, G., Martinez, M.C., Margalef, M.I. (2001). How Argentine consumers understand the Spanish translation of the 9-point hedonic scale. Food Quality and Preference 12, 217-221. doi: 10.1016/s0950-3293(01)00012-x.

21. Bornstein, M. H., Jager, J., \& Putnick, D. L. (2013). Sampling in developmental science: Situations, shortcomings, solutions, and standards. Developmental Review, 33(4), 357-370. https://doi.org/10.1016/j.dr.2013.08.003.

22. Deliza, R., MacFie, H.J.H. (1996). The generation of sensory expectation by external cues and its effect on sensory perception and hedonic ratings: A review. Journal of Sensorial Studies, 11, 103-128. doi.org/10.1111/j.1745-459X.1996.tb00036.x.

23. Schifferstein, H.J.N. (1995). Contextual shifts in hedonic judgment. Journal of Sensorial Studies, 10, 381-392. doi.org/10.1111/j.1745459X.1995.tb00027.x.

24. Kahkonen, P., Tuorila, H., Hyvonen, L. (1995). Dairy fact content and serving temperature as determinants of sensory and hedonic characteristics of cheese soup. Food Quality and Preference, 6, 127-133. doi.org/10.1016/0950-3293(95)98555-W. 